\title{
Development of High Power Anode Material for Automotive Li-ion Batteries
}

\author{
Dr. Bharat S Chahar ${ }^{1}$ and Dr. Zhenhua Mao \\ ${ }^{I}$ Corresponding author \\ ConocoPhillips Co., \\ 600 N. Dairy Ashford, Houston, TX 77079, USA \\ Bharat.s.Chahar@conocophillips.com \\ Zhenhua.Mao@conocophillips.com
}

\begin{abstract}
ConocoPhillips has engaged in research and development of carbonaceous materials as anode material for lithium ion batteries for the past 10 years and developed a technology platform for producing graphite anode materials for Li-ion batteries (Li-B). The CPreme ${ }^{\circledR}$ graphite powders were developed as anode material for Li-ion batteries, specifically addressing the challenging needs of $\mathrm{Li}-\mathrm{B}$ in automotive and other high-power applications. The CPreme ${ }^{\circledR}$ graphite powders provide excellent combination of power, energy density, long cycle life and safety. This presentation provides details behind the technology platform used in making CPreme ${ }^{\circledR}$ graphites. Examples of how CPreme ${ }^{\circledR}$ graphites can help the LiB manufacturers meet the difficult requirements of future automobiles are discussed.
\end{abstract}

Keywords: graphite, anode, lithium-ion batteries, power, cycle life

\section{Introduction}

ConocoPhillips is a global integrated energy company with extensive petroleum refining capability. One of the main differentiations between ConocoPhillips and other major refining companies is the expertise ConocoPhillips has developed in converting heavy hydrocarbons to lighter fuels by delayed coking. One by-product of the delayed coking process is petroleum coke. While most refiners dispose of petroleum coke as a solid fuel, ConocoPhillips has been producing high value specialty cokes and other carbon products from petroleum for approximately 50 years and is a leading supplier of graphite grade coke to electric arc furnace electrode manufacturers worldwide for the production of steel. Using this background, ConocoPhillips launched a R\&D effort in the late 1990s to develop graphite based anode powders for high performance and high power Li-ion batteries. This effort has resulted in commercialization of CPreme $^{\circledR}$ graphite powders that are finding increasing acceptance in the $\mathrm{Li}$-ion batteries targeted for electrical vehicles slated for rollout in the next few years. This paper describes some of the technology behind development of CPreme $^{\circledR}$ graphite materials and how these materials can play a critical role in the future of transportation industry.

\section{Technology Platform}

The ConocoPhillips technology platform for producing graphite anode materials consists of two major aspects: a) creating desirable particle morphology and b) making desirable bulk and 
surface properties. Based on different requirements of Li-ion batteries for different applications, anode materials with different particle size, shape and electrochemical properties can be made with the ConocoPhillips process. While portable power applications require high energy density and thermal safety, large Li-B targeted for automotive applications need higher power, much longer cycle life, a significantly improved safety profile and lower cost. These performance requirements were addressed in the following manner in the development of CPreme ${ }^{\circledR}$ technology platform:

\subsection{Power and Safety}

By studying the power performance of various particle size graphite powders, we were able to determine that anodes made with graphite powders having smaller particle diameter are able to deliver more power. While power performance can be increased by lowering the average particle size of graphite powder, lower particles also result in higher surface area of the anode material. The relationship between higher graphite surface area and lower first cycle efficiency in Li-B has been well established [1, 2]. Lower first cycle efficiency also is known to result in undesired thermal instability [2] and large change in electrode dimension during charge and discharge [3]. The CPreme ${ }^{\circledR}$ products were designed to have small particle size to achieve the desirable power capability and at the same time to have a minimum specific surface area to achieve the high thermal stability and calendar life [4].

In late 1990s, ConocoPhillips had developed a new process to make mesophase pitch from petroleum feedstock. Using this background, we found a novel way to coat a powder with a carbon layer that would cover the entire surface of a particle and reduce any surface cracks and dislocations. This invention resulted in the development of a process that can reduce the surface area of graphitic particles and improve first cycle efficiency of graphite materials.

\subsection{Cycle Life and Cost:}

While the coating process described above can be used to improve safety characteristics and first cycle efficiency of any graphite material, we wanted to find a base material that would provide a long cycle life and still be cost effective. We studied several starting materials for the development of CPreme ${ }^{\circledR}$ anode material and determined that petroleum coke based material would fit these two criteria. Since petroleum cokes are produced in a refinery as a byproduct, the raw materials for Li-B anode powder can be secured at a low cost. Several million metric tons of petroleum cokes are produced worldwide - thus the abundant petroleum cokes would certainly meet the needs of the Li-B industry regardless of growth for the foreseeable future. ConocoPhillips alone produces petroleum coke with varying properties in 12 refineries across the globe.

Also, coke is produced in large chunks in a delayed coker and has to be ground to make powder. Therefore, each particle in a coke based powder is a singular entity and can have excellent structural integrity. This is important for Li-B anode application as the anode material goes through expansion and contraction of about $10 \%$ during every charge and discharge cycle $[3$, 5], and we believe maintaining structural integrity during cycling is key to long cycle life. Petroleum coke for CPreme ${ }^{\circledR}$ graphites is carefully chosen from the large inventory of petroleum cokes available in the ConocoPhillips refining system to ensure a highly graphitic and low impurity final product with good structural strength.

\subsection{CPreme ${ }^{\circledR}$ Production Process}

After selecting the desired raw material (petroleum coke) from the refinery, coke is ground into a powder of desired size. Milled coke powder is then coated with a carbon layer of desirable crystalline structure. The coated coke powder is finally graphitized at a desirable temperature to achieve the physical and electrochemical properties as required for different applications. The CPreme ${ }^{\circledR}$ material is sieved to ensure removal of any large agglomerated particles before packaging for shipment. The process to produce CPreme ${ }^{\circledR}$ graphite can be automated at a large production scale thus allowing low cost production to meet the automotive industry need. Figure 1 shows a flow diagram of the production process with descriptions of the functionality of each step. 
Selection of graphitizable cokes and sizing of particles

Coating of

desirable carbon layer

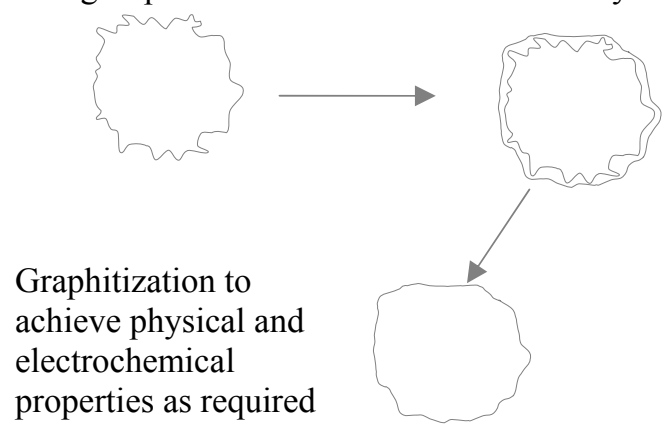

Figure 1: A schematic flow diagram of the CPreme $^{\circledR}$ production process

Currently ConocoPhillips is commercially producing three grades of CPreme ${ }^{\circledR}$ graphite powders targeted for different segments of the automotive industry (Tables 1 and 2). The smallest particle size product, CPreme ${ }^{\circledR}$ G5 with average size of 5 microns is ideally suited for the HEV applications, 8-micron product CPreme ${ }^{\circledR}$ G8 is designed for PHEVs and CPreme ${ }^{\circledR}$ G15 will work well in the EV platform.

Table 1: Physical Properties of CPreme ${ }^{\circledR}$ graphite products.

\begin{tabular}{|c|c|c|c|c|}
\hline \multicolumn{2}{|c|}{ Material } & $\begin{array}{c}\text { CPreme }^{\circledR} \\
\text { G15 }\end{array}$ & $\begin{array}{c}\text { CPreme }^{\circledR} \\
\text { G8 }\end{array}$ & $\begin{array}{c}\text { CPreme }^{\circledR} \\
\text { G5 }\end{array}$ \\
\hline \multirow{3}{*}{$\begin{array}{c}\text { Particle } \\
\text { Size (mm) }\end{array}$} & $D_{90}$ & $27-30$ & $13-14$ & $10-12$ \\
\hline & $D_{50}$ & $13-17$ & $7-9$ & 4-6 \\
\hline & $D_{10}$ & $5-9$ & 3-4 & 3-4 \\
\hline \multicolumn{2}{|c|}{ BET area $\left(\mathrm{m}^{2} / \mathrm{g}\right)$} & $0.7-1.0$ & $1.5-2$ & $2.0-3.0$ \\
\hline \multicolumn{2}{|c|}{ Tap density (g/cc) } & 1.0-1.1 & $0.8-0.9$ & $0.7-0.8$ \\
\hline \multirow{2}{*}{ XRD } & $\mathrm{D}_{002}(\mathrm{~nm})$ & 0.336 & 0.336 & 0.336 \\
\hline & $\mathrm{L}_{\mathrm{c}}(\mathrm{nm})$ & 370 & 370 & 370 \\
\hline
\end{tabular}

Table 2: Electrochemical properties of CPreme ${ }^{\circledR}$ graphite products. Fine mesophase carbon micron beads (MCMB, average size of 10 micron meters) and Natural Graphite (NG) products are commercial products from other companies.

\begin{tabular}{|c|c|c|c|}
\hline Material & $\begin{array}{l}\text { Reversible } \\
\text { Capacity } \\
\text { (mAh/g) }\end{array}$ & $\begin{array}{l}\text { Irreversible } \\
\text { Capacity } \\
\text { (mAh/g) }\end{array}$ & $\begin{array}{l}\text { Initial } \\
\text { Coulombic } \\
\text { Efficiency (\%) }\end{array}$ \\
\hline CPreme® G15 & $330-340$ & $\sim 19$ & 95 \\
\hline CPreme® G8 & $320-335$ & $\sim 18$ & 95 \\
\hline CPreme® G5 & $315-330$ & $\sim 20$ & 94 \\
\hline Fine MCMB & 300 & $\sim 30$ & 91 \\
\hline Fine NG & 360 & $\sim 50$ & 88 \\
\hline
\end{tabular}

The three commercial CPreme ${ }^{\circledR}$ products have been designed to have very high coulombic efficiency compared to other commercial graphite anode powders. Also, these graphite anode materials are compatible with the leading cathode materials such as lithium nickel cobalt oxides and lithium iron phosphate. In addition, the physico-chemical property of the carbon coating layer can be altered to modify not only the electrode potential profile of the final material but also the coulombic efficiency so that the materials can be compatible with some new cathode materials, as desired.

\section{Performance Comparison}

\subsection{Power Capability}

To compare the power capability of CPreme ${ }^{\circledR}$ G5 with an industry standard MCMB anode, several $9 \mathrm{~cm}^{2}$ lab cells were made using lithium nickel cobalt oxide (NCA, $\mathrm{LiNi}_{0.8} \mathrm{Co}_{0.2} \mathrm{O}_{2}$ ) cathode. Figure 2 shows the discharge capacity of cells made with the two materials as a function of discharge rate and it clearly shows CPreme ${ }^{\circledR}$ G5 to have superior capability in this performance criteria. The performance differences are enhanced when the tests were run at $-15^{\circ} \mathrm{C}$. 


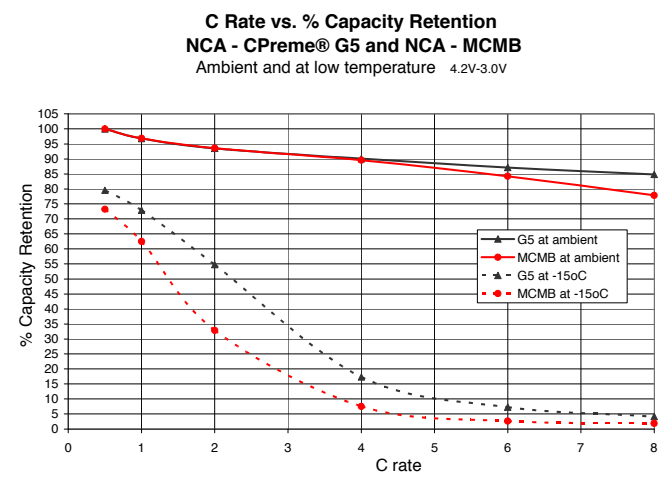

Figure 2: Power Capability Comparison

\subsection{Cycle Life}

The cycle life of cells described above was compared by cycling them to $100 \%$ DOD at $\mathrm{C} / 2$ rate. The results are shown in Figure 3. Here CPreme ${ }^{\circledR}$ G5 cells appear to hold their capacity better than the cells with MCMB.

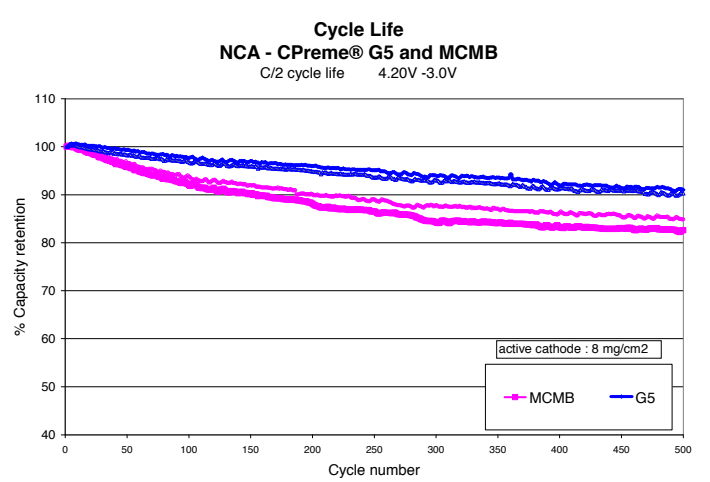

Figure 3: Cycle Life Comparison

\subsection{Shelf Life Comparison}

Long calendar life of batteries is a critical performance parameter in automotive applications [6]. Accelerated shelf life tests are carried out at elevated temperatures to compare this property of cells. To test the shelf life characteristic of different anode materials, coin cells made with several batches of CPreme ${ }^{\circledR} \mathrm{G} 8$ and $\mathrm{MCMB}$ were stored at $70^{\circ} \mathrm{C}$ for 72 hours after these electrodes were fully cycled three times and then charged to the same state-ofcharge at $300 \mathrm{mAh} / \mathrm{g}$. The remaining capacity and the capacity loss of cells were measured after this storage period and are compared in Figure 4. Although there is some variation from one cell to another for $\mathrm{CPreme}^{\circledR} \mathrm{G} 8$, all cells made with CPreme $^{\circledR}$ G8 show lower loss in capacity compared to MCMB.

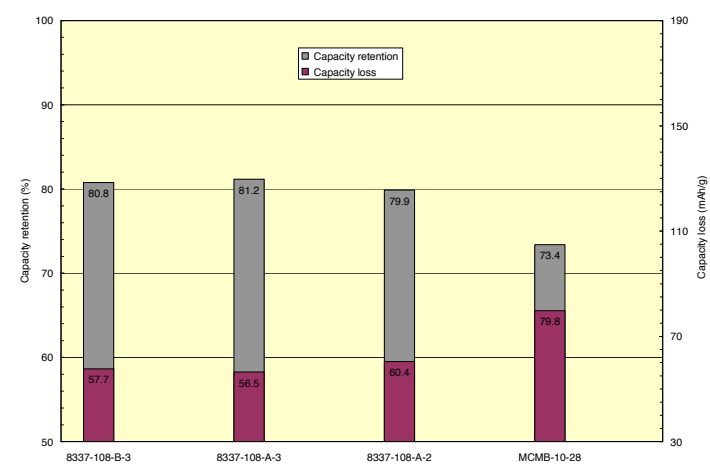

Figure 4: Capacity Retention Comparison after 72 hours Storage at $70^{\circ} \mathrm{C}$.

\subsection{Safety}

Safety is a key concern for large, high power and high energy cells required for automotive applications. Li-Bs have had some issues with spontaneous fires in smaller applications such as laptops [7]. Toyota cited safety issues as one concern for delaying introduction of Li-B in its automobiles [8]. We have demonstrated how anode selection can significantly enhance Li-B safety and heat release performance. Thermal stability of several anode materials was tested by using a differential scanning calorimetry (DSC) technique $[2,4]$. In this technique, coin cells made with various anode materials are cycled three times before the test begins to ensure the cell reaches a stable operating condition. The cell is charged to $300 \mathrm{mAhr} / \mathrm{g}$ anode and is disassembled. Charged anode is placed in a DSC cell and the temperature of the DSC cell is raised at a constant rate. Heat flow from the DSC cell is measured as a function of DSC cell temperature. By comparing the heat generated by various anode materials, one can deduce the relative thermal stability of the anode material being tested. A comparison of heat generated by various anode materials is shown in Table 3 in two different temperature ranges. Higher heat generation in this table indicate less thermally stable material. As shown in Table 3, CPreme ${ }^{\circledR}$ materials have the lowest heat generation of any materials compared. This leads us to believe that $\mathrm{CPreme}^{\circledR}$ anode can be used in designing and building a safer battery compared to other graphites. 
Table 3. Heat generated by various anode materials in a DSC test.

\begin{tabular}{|c|c|c|c|c|c|}
\hline $\begin{array}{c}\text { CPreme }^{\text {क }} \\
\text { Graphite } \\
\text { name }\end{array}$ & $\begin{array}{c}\text { Particle } \\
\text { size } \\
\text { (D50, } \\
\text { mm) }\end{array}$ & $\begin{array}{l}\text { Specific } \\
\text { capacity } \\
\text { (mAh/g) }\end{array}$ & $\begin{array}{c}\text { Initial } \\
\text { irreversible } \\
\text { capacity } \\
\text { loss } \\
(\mathrm{mAh} / \mathrm{g})\end{array}$ & $\begin{array}{c}\text { Total } \\
\text { heat } \\
(110- \\
2200 C) \\
(J / g) \\
\end{array}$ & $\begin{array}{c}\text { Total } \\
\text { heat* } \\
(220- \\
3000 C) \\
(J / g)\end{array}$ \\
\hline $\begin{array}{c}\text { CPreme }^{\circledR} \\
\text { G5 }\end{array}$ & 5 & 315 & 20 & 290 & 582 \\
\hline $\begin{array}{c}\text { CPreme }^{\circledR} \\
\text { G8 }\end{array}$ & 8 & 325 & 15 & 285 & 575 \\
\hline $\begin{array}{c}\text { CPreme }^{\circledR} \\
\text { T8* }\end{array}$ & 8 & 324 & 15 & 196 & 480 \\
\hline $\begin{array}{l}\text { MCMB } \\
\text { graphite }\end{array}$ & 10 & 305 & 27 & 400 & 676 \\
\hline $\begin{array}{c}\text { Coated } \\
\text { NG }\end{array}$ & 22 & 358 & 27 & 288 & 730 \\
\hline $\begin{array}{l}\text { Synthetic } \\
\text { graphite }\end{array}$ & 21 & 361 & 33 & 347 & 862 \\
\hline
\end{tabular}

* CPreme ${ }^{\circledR}$ product under development

\section{Future Products}

Since each step of the CPreme ${ }^{\circledR}$ graphite process can be controlled independently and carbon coating using the method discovered by ConocoPhillips can be applied to any raw material, this technology platform affords enormous flexibility in designing and developing new products. As we mentioned earlier in this paper, ConocoPhillips has access to a wide variety of petroleum cokes with different crystal structure, impurity level and volatile content. Also, these coke materials can be milled to almost any average particle size and distribution. With some control on the particle shape, one can easily customize CPreme ${ }^{\circledR}$ products to meet different customer needs. Also, the technology platform enables the development of new products to meet the evolving needs of the industry. Examples of possible new products that further enhance some of the key properties of current CPreme $^{\circledR}$ graphites are shown in Table 4.

Observing the properties of CPreme ${ }^{\circledR} \mathrm{N} 3 \mathrm{X}$ shows that it is possible to produce material even lower in particle size than the current $\mathrm{CPreme}^{\circledR}$ G5 product and still maintain good capacity, first cycle efficiency and reasonable surface area. Product such as CPreme ${ }^{\mathbb{B}}$ T8 may be useful for applications where higher density anodes may be needed. Comparison of the DSC profile of CPreme ${ }^{\circledR}$ T8 from Table 3, shows that lower heat generating materials than the current $\mathrm{CPreme}^{\circledR}$ G8 or G5 products is still possible, thus providing even safer graphitic anode materials in the future.
Table 4: Selected properties of products under development.

\begin{tabular}{|c|c|c|c|}
\hline CPreme $^{\circledR}$ Product & N3X & T8 & DG8 \\
\hline $\begin{array}{c}\text { First Cycle Capacity, } \\
\text { mAhr/g }\end{array}$ & 310 & 330 & 334 \\
\hline First Cycle Efficiency, \% & 93 & 96 & 95 \\
\hline Real Density, g/cc & 2.22 & 2.17 & 2.24 \\
\hline Tap Density, g/cc & 0.7 & 1.1 & 0.9 \\
\hline PSD, $\mu$ & & & \\
\hline D10 & 1.5 & 4.2 & 3.9 \\
\hline D50 & 3.9 & 8.7 & 7.7 \\
\hline D90 & 7.6 & 16.1 & 13.8 \\
\hline $100 \%$ & 22 & 41 & 37 \\
\hline BET Surface Area, m2/g & 3.2 & 1.1 & 1.4 \\
\hline
\end{tabular}

\section{Summary}

ConocoPhillips has developed a platform technology that allows production of safer, longer lasting and high power capable anode materials for Li-B. These materials are expected to help achieve the battery performance that is needed for vehicles of the future. The technology platform allows further optimization of current anode materials and for future development of new graphite based anode products.

\section{Acknowledgments}

We acknowledge contributions from many colleagues at ConocoPhillips and experimental work done by Dr. Shanthi Korutla (formerly of Lithium Technology Corp.) on behalf of ConocoPhillips.

\section{References}

[1] Zhenhua Mao et al, Proceedings, AABC 2008, Tampa, Fl, 2008-5-16

[2] Felix Joho, et al., Journal of The Electrochemical Society, 149 (8) A1020-A1024 (2002)

[3] M. Hanhn et al. Electrochemical and Solid-State Letters, 11 _ _ A151-A154 (2008)

[4] Zhenhua Mao, et al. Extended abstract \#, Proceeding of $14^{\text {th }}$ International Meeting of Lithium ion batteries, Tianjin China, June 2008. 
[5] D. Billaud, E. McRae, and A. Hérold, Mater. Res. Bull., 14, 857 (1979).

[6] USCAR Goals for HEV and EV, www.uscar.org, Accessed on March 17, 2009.

[7] News from CPSC, "Sony Recalls Notebook Computer Batteries Due to Previous Fires", www.cpsc.gov, Accessed on March 17, 2009.

[8] N. Shirouzu, "Toyota Delays Next Hybrids on Safety concerns", Wall Street Journal, Page B1, August 9, 2007

\section{Authors}

Dr. Bharat Chahar is Product Manager for CPreme ${ }^{\circledR}$ Energy Storage Materials in ConocoPhillips. He has been with

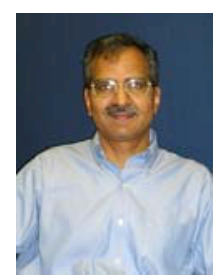
ConocoPhillips in many $R \& D$ and new business development roles since 1981 and is author of many papers and patents. He holds a Ph.D. in Chemical Engineering from Rice University and is registered professional engineer in the State of Oklahoma.

Dr. Zhenhua Mao is Principal Scientist with Technology - Research and Development of ConocoPhillips. He has been involved in research and development of lithium ion batteries since 1993. He holds a $\mathrm{Ph} \mathrm{D}$. in Chemical Engineering from Texas A\&M University. 